Article

\title{
High-Temperature Tribological Behavior of the Ti-22Al-25Nb (at. \%) Orthorhombic Alloy with Lamellar O Microstructures
}

\author{
Wei Wang ${ }^{1}{ }^{\mathbb{D}}$, Haixiong Zhou ${ }^{1}$, Qingjuan Wang ${ }^{1, *}$, Jie Jin ${ }^{2, *}$, Yaling Sun ${ }^{1}$ and Kuaishe Wang ${ }^{1}$ \\ 1 School of Metallurgy Engineering, Xi'an University of Architecture and Technology, Xi'an 710055, China; \\ gackmol@163.com (W.W.); haixiong@live.xauat.edu.cn (H.Z.); sunyaling@live.xauat.edu.cn (Y.S.); \\ wangkuaishe888@126.com (K.W.) \\ 2 State Key Laboratory of Tribology, Tsinghua University, Beijing 100084, China \\ * Correspondence: jiandawqj@163.com (Q.W.); jjking@mail.tsinghua.edu.cn (J.J.)
}

Received: 16 November 2018; Accepted: 17 December 2018; Published: 20 December 2018

\begin{abstract}
Tribological behavior of the isothermally forged and heat-treated Ti-22Al-25Nb (at. \%) orthorhombic alloy with lamellar $\mathrm{O}$ microstructures was investigated. The friction experiments using a tribometer (UMT-3 CETR) against $\mathrm{Si}_{3} \mathrm{~N}_{4}$ and $\mathrm{Al}_{2} \mathrm{O}_{3}$ were conducted at the load of $10 \mathrm{~N}$ from 20 to $750{ }^{\circ} \mathrm{C}$ and a constant speed of $0.188 \mathrm{~m} / \mathrm{s}$. The experiment results indicated that for the friction pair of $\mathrm{Al}_{2} \mathrm{O}_{3}$, the coefficient of friction (COF) was decreased from 0.906-0.359, and for the friction pair of $\mathrm{Si}_{3} \mathrm{~N}_{4}$, COF was decreased from 0.784-0.457 as the friction temperature increased from room temperature to $750{ }^{\circ} \mathrm{C}$. The wear rate of the alloy against $\mathrm{Al}_{2} \mathrm{O}_{3}$ is in the range of $2.63-8.15 \times 10^{-4} \mathrm{~mm}^{3} \mathrm{~N}^{-1} \mathrm{~m}^{-1}$, the wear rate against $\mathrm{Si}_{3} \mathrm{~N}_{4}$ is in the range of 2.44-5.83 $\times 10^{-4} \mathrm{~mm}^{3} \mathrm{~N}^{-1} \mathrm{~m}^{-1}$, respectively. The wear mechanisms of the alloy were changed from plastic deformation and ploughing at lower temperature $\left(20-400{ }^{\circ} \mathrm{C}\right)$ to adhesive wear and oxidative mechanism at higher temperature $\left(600\right.$ and $\left.750{ }^{\circ} \mathrm{C}\right)$. The friction and wear behavior of the $\mathrm{Al}_{2} \mathrm{O}_{3}$ friction pair was comparable to that of the $\mathrm{Si}_{3} \mathrm{~N}_{4}$ friction pair.
\end{abstract}

Keywords: $\mathrm{Ti}_{2} \mathrm{AlNb}$-based alloys; orthorhombic; tribological properties

\section{Introduction}

Among titanium aluminides, the orthorhombic $\mathrm{Ti}_{2} \mathrm{AlNb}$-based alloys have higher ductility, higher yield strength, and better elevated temperature strength and fracture toughness [1-3]. Hence, considerable interest has been given to the $\mathrm{Ti}_{2} \mathrm{AlNb}$-based alloys for various applications in aerospace components [4,5]. Over past decades, research in $\mathrm{Ti}_{2} \mathrm{AlNb}$-based alloys was mainly focused on how to improve the mechanical properties of the alloys through alloying, thermo-mechanical processing and heat treatment etc. [1-7]. At present, many aviation components which were made by $\mathrm{Ti}_{2} \mathrm{AlNb}$-based alloys are fitted in a trial run engine [8]. The $\mathrm{Ti}_{2} \mathrm{AlNb}$-based alloys can be used as the rotating components like turbine blades and valves, in this situation, this alloy will be subjected to friction and wear. However, wear resistance of $\mathrm{Ti}_{2} \mathrm{AlNb}$-based alloys is much lower. This problem limited some practical applications of the $\mathrm{Ti}_{2} \mathrm{AlNb}$-based alloys at high temperatures. There is the fretting wear in low-pressure turbine blades and disks when aero engines are running at great speed. The fretting wear at the dovetail was always happened [9]. Hence it is very important to investigate the high-temperature tribological properties of $\mathrm{Ti}_{2} \mathrm{AlNb}$-based alloys [10].

Consequently, in recent years there is a lot of research into the tribological performance of TiAl-based alloys [10-15]. Li et al. [11] have studied the sliding wear of TiAl intermetallics against different counterface materials, focusing on the response of the counterface materials and wear 
mechanism. Alam et al. [12] have investigated dry sliding wear of Ti-24Al-11Nb alloys and found that the delamination and oxidative wear are two main wear mechanisms. Rastkar et al. [13] have researched the sliding wear behavior of lamellar Ti-48Al-2Nb-2Mn (at. \%) and Ti-45Al-2Nb-2Mn-1B (at. \%) alloys, the plastic deformation and ploughing were two main friction characteristics. These investigations were mainly focused on the wear and friction properties of TiAl-based alloys at room temperature. The researches about friction and wear behavior of TiAl-based alloys at high temperature are relative less. Few investigations have been done on high-temperature tribological behavior. Miyoshi et al. [14] have investigated the fretting wear behavior of Ti-48Al-2Cr-2Nb alloy in air at the temperature from $23{ }^{\circ} \mathrm{C}$ to $550{ }^{\circ} \mathrm{C}$, Cheng et al. [15] have studied the tribological behavior of Ti-46Al-2Cr-2Nb alloy at the temperature from 20 to $900{ }^{\circ} \mathrm{C}$. However, to the author's knowledge, previous studies were focused on the tribological performance of TiAl-based alloys which were made by powder metallurgy. $\mathrm{Ti}_{2} \mathrm{AlNb}$-based alloys are different from the TiAl alloys, and the tribological properties of the Ti-22Al-25Nb alloy which was produced by casting and forging were never reported. This mechanical index is very critical for the high temperature application of Ti-22Al-25Nb alloy. Thus, it is very important to further study the tribological behavior of Ti-22Al-25Nb alloy at high temperature.

The aim of this paper is to study the friction and wear of the Ti-22Al-25Nb (at. \%) orthorhombic alloy which produced by casting and forging. The counter face materials are $\mathrm{Si}_{3} \mathrm{~N}_{4}$ and $\mathrm{Al}_{2} \mathrm{O}_{3}$ ball, respectively. Here we try to understand the wear mechanism of this alloy from room temperature to $750{ }^{\circ} \mathrm{C}$.

\section{Materials and Experiments}

The forged Ti-22Al-25Nb alloy obtained from non-ferrous metal research (NIN), China, and was heat treated at $800{ }^{\circ} \mathrm{C}$ to improve mechanical properties of this alloy [7]. In past research, this heat treatment schedule is the better choice. The phase structure and microstructure of starting materials are presented in Figure 1. Figure 1a is the X-ray diffraction (XRD) analysis results of the forged and then heat treated alloy at $800{ }^{\circ} \mathrm{C}$, from the results, it can be seen that $\mathrm{B} 2$ and $\mathrm{O}$ phase were presented in this alloy. The phase structures of the $\mathrm{O}$ phase alloys are different from that of commercial titanium alloys. It includes several different phase types: orthorhombic phase $(\mathrm{O})\left(\mathrm{Cmcm}\right.$ system based on $\left.\mathrm{Ti}_{2} \mathrm{AlNb}\right)$, hexagonal close-packed (hcp) $\alpha_{2}$ phase $\left(\mathrm{DO}_{19}\right.$ structure base on $\mathrm{Ti}_{3} \mathrm{Al}$ ) and bcc phase $\beta$ (disordered body-centered cubic structure) or B2 phase (ordered body-centered cubic structure). The (111), (220), (040), (221), (041), (151), (113) and (223) are all the diffraction peaks of the O phase, the (101), (201), (112) and (220) are all the diffraction peaks of the B2 phase. All the peaks in the pattern can be assigned to that of standard orthorhombic $\mathrm{Ti}_{2} \mathrm{AlNb}$ (JCPDS (Joint Committee on Powder Diffraction Standards) No. 53-0485). It means that the alloy contained B2 and O phase. Figure $1 \mathrm{~b}$ was the SEM image of the initial alloy. The chemical composites of three phase such as B2, $\alpha_{2}$ and $\mathrm{O}$ phase are different, the colors are also different in the scanning electron microscope (SEM) image with back scatter electron (BSE) model. Thus, in this image, the gray regions are $\mathrm{O}$ phases, and light regions are B2 phases. In its current state, $\mathrm{B} 2$ phases have higher volume fraction. The size of the lamellar $\mathrm{O}$ phase is smaller. It is not benefit for improving the strength of this alloy. In order to improve the comprehensive performances of this alloy, the forged alloy was then heat treated at $800{ }^{\circ} \mathrm{C}$ for $3 \mathrm{~h}$ and then water quenched. Figure $1 \mathrm{c}$ is the heat-treated microstructure, more fine-lamellar $\mathrm{O}$ phases were precipitated from $\mathrm{B} 2$ matrix, and the size of the lamellar $\mathrm{O}$ phase was coarser. From Figure 1d, the more fine-lamellar $\mathrm{O}$ phases of about $50 \mathrm{~nm}$ were precipitated from the residual B2 matrix. 


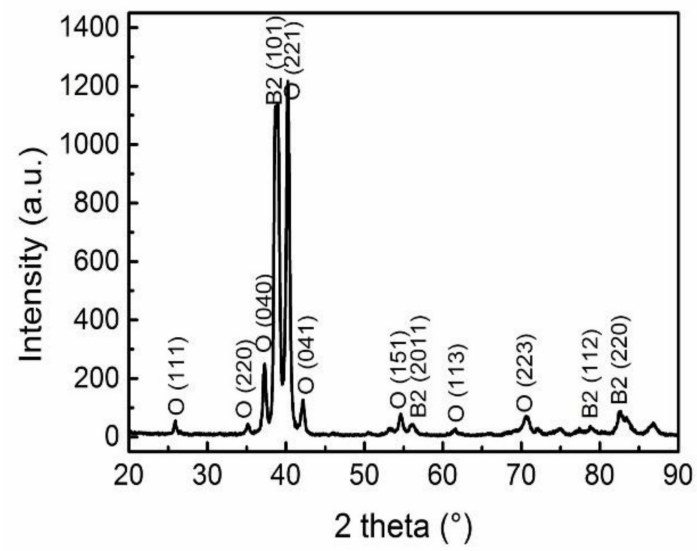

(a)

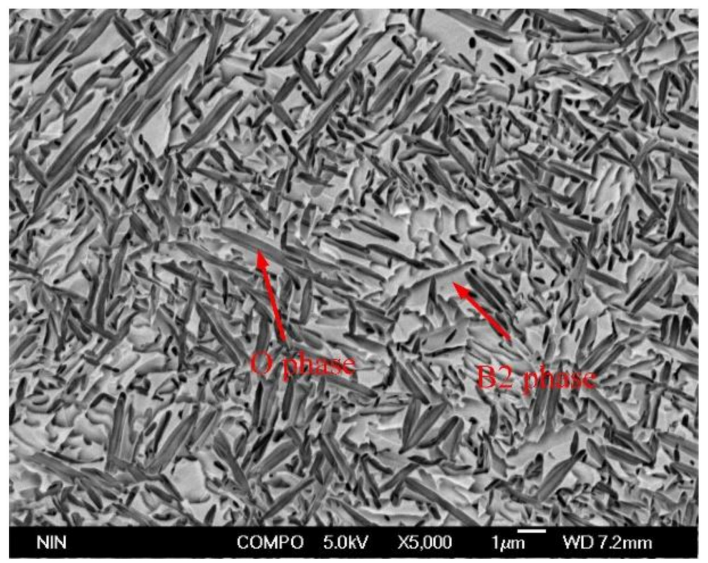

(c)

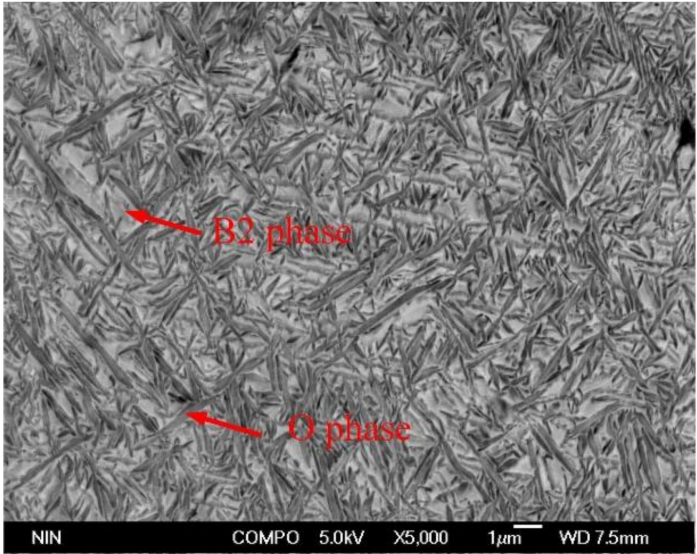

(b)

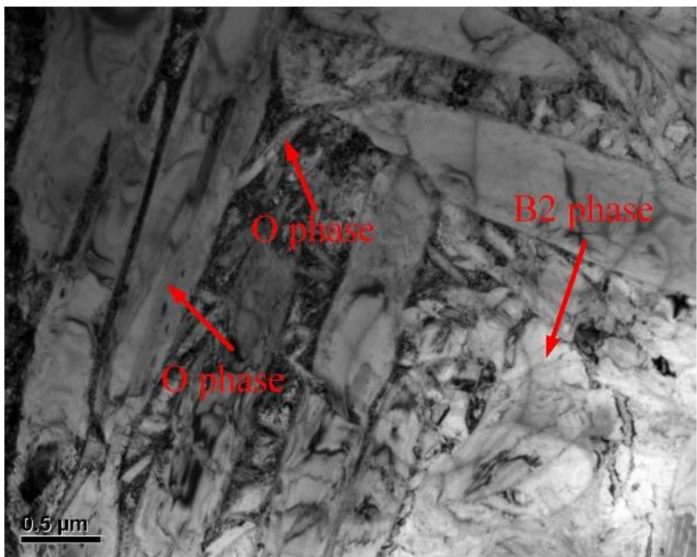

(d)

Figure 1. Phase and microstructure of the initial alloys: (a) X-ray diffraction (XRD) image of the forged and then heat treated alloy at $800^{\circ} \mathrm{C},(\mathbf{b})$ scanning electron microscope (SEM) image of the forged alloys, (c) SEM image of the forged and then heat-treated alloys at $800{ }^{\circ} \mathrm{C}$, (d) transmission electron microscope (TEM) image of the forged and then heat treated alloys at $800{ }^{\circ} \mathrm{C}$ (the gray is $\mathrm{O}$ phase and light regions are B2 in Figure 1b,c).

Friction experiments of Ti-22Al-25Nb alloy were conducted in a ball-on-disk mode using the Universal Micro-Tribotester (UMT-3, Bruker, Karlsruhe, Germany). Figure 2 is the schematic diagram of the high-temperature ball-on-disk tribometer. The temperatures of this experimental were selected to be $20,200,400,600$ and $750{ }^{\circ} \mathrm{C}$. The dimension of the disk was $\phi 50 \times 8 \mathrm{~mm}$ and against a stationary commercial $\mathrm{Si}_{3} \mathrm{~N}_{4}$ ball and $\mathrm{Al}_{2} \mathrm{O}_{3}$ ball of $\phi 10 \mathrm{~mm}$ in diameter. The surfaces of the disks were polished by standard metallographic techniques. The sliding speed was $0.188 \mathrm{~m} / \mathrm{s}$ with a wear track diameter of $15 \mathrm{~mm}$. The applied load was $10 \mathrm{~N}$, and the sliding time was $30 \mathrm{~min}$. The coefficient of friction (COF) was recorded automatically. The wear rate was calculated by the reference [16], $W=V /\left(P^{*} S\right)$. In this formulation, $\mathrm{W}$ is the wear rate, $\mathrm{V}$ is the wear volume, $\mathrm{P}$ is the applied load, and $\mathrm{S}$ is the total sliding distance. Wear volume of the Ti-22Al-25Nb alloy was obtained by the three dimensional white-light interfering profilometer from the lower specimens Ti-22Al-25Nb alloy disc. In order to make sure the reliability of the data, all the data were detected three times. In this investigation, a SEM (scanning electron microscope) model JSM-5600LV (Jeol Co., Tokyo, Japan) and EDS (energy dispersive spectroscopy, Jeol Co., Tokyo, Japan) were used for evaluating the microstructure of the initial, heat treatment, and the frictional alloys. The heat-treated samples were mechanically polished using a standard metallographic method. Specimens were polished and etched chemically using 
HF: $\mathrm{HNO}_{3}: \mathrm{H}_{2} \mathrm{O}$ (1:3:5) with the volume fraction. The surface roughness of the final disc is about $200 \mu \mathrm{m}$. In order to evaluate the chemical state and the product of friction, XRD (JDX-3530M, JEOL, Tokyo, Japan) and XPS (X-ray photoelectron spectroscopy, Phi-5000 Versa Probe; ULVCA-PHI, USA) were used in this investigation. The phase structure of the Ti-22Al-25Nb alloy was evaluated by XRD at a $2 \theta$ scan range of $10-90^{\circ}$, with the scan rate of $4^{\circ} / \mathrm{min}$. The XRD data was acquired using a Rigaku Smart Lab (Cu source, operating at $40 \mathrm{kV}$ and $40 \mathrm{~mA}$ ) equipped with a parallel point focus incident beam (CBO-f optic). The XPS analyses were performed using the Al Ka X-ray source (1486.6 $\mathrm{eV})$. Survey spectra were recorded with a pass energy of $100 \mathrm{eV}$, and high-resolution spectra of the $\mathrm{A} 12 \mathrm{p}$, Ti2p and O1s core level regions were recorded with a pass energy of $20 \mathrm{eV}$. Angle-resolved measurements were performed by varying the take-off angle (angle of the analyzed photoelectrons with respect to the surface plane). Peak fitting allowing to decompose the XPS spectra in different components assigned to different surface species was performed using the ECLIPSE software (ME600L microscope, Nikon, Tokyo, Japan) and a Shirley background. The procedure was established using reference spectra obtained on well-defined samples. White-light-interferometry measurements were performed. A high-performance white-light-interferometer with a lateral resolution of $0.8 \mu \mathrm{m}$ and vertical resolution of $0.1 \mathrm{~nm}$ was used to perform depth measurements after the wear experiments. The wear volume was calculated automatically by the equipment using the integral method.

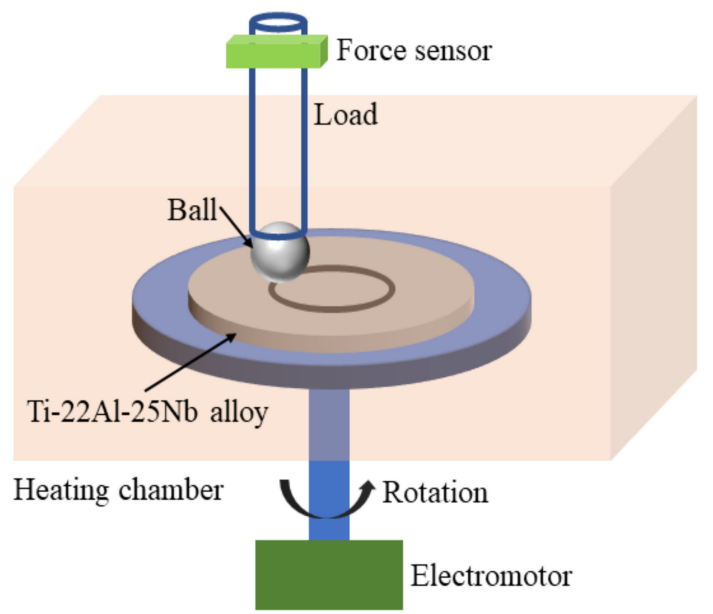

Figure 2. The schematic diagram of the high-temperature ball-on-disc tribometer used in this work.

\section{Results and Discussion}

\subsection{High Temperature Tribological Properties of Ti-22Al-25Nb Alloy}

The COFs and wear rates of the Ti-22Al-25Nb alloy with testing time of 1800 seconds at different counterface materials and temperatures are shown in Figure 3. COFs of this alloy against $\mathrm{Al}_{2} \mathrm{O}_{3}$ and $\mathrm{Si}_{3} \mathrm{~N}_{4}$ ball were presented in Figure $3 \mathrm{a}$, it can be seen that two counterface materials present similar COFs. As the test temperature $\left(20-750{ }^{\circ} \mathrm{C}\right)$ increased, the COFs decreased. However, the COFs at low and high temperatures are different. The $\mathrm{COF}$ of $\mathrm{Al}_{2} \mathrm{O}_{3}$ is higher than that of $\mathrm{Si}_{3} \mathrm{~N}_{4}$ below $400{ }^{\circ} \mathrm{C}$, while the trends are going in the other direction at $400-750{ }^{\circ} \mathrm{C}$. It means that the frictional mechanism is different above and below $400^{\circ} \mathrm{C}$. Figure $3 \mathrm{~b}$ is the wear rate of this alloys vs. $\mathrm{Si}_{3} \mathrm{~N}_{4}$ and $\mathrm{Al}_{2} \mathrm{O}_{3}$ at different testing temperatures. It can be seen that wear rates of this alloys vs. $\mathrm{Al}_{2} \mathrm{O}_{3}$ are higher than that of this alloys vs. $\mathrm{Si}_{3} \mathrm{~N}_{4}$ at the same temperature as the temperature increased. The wear rate of the Ti-22Al-25Nb alloy against $\mathrm{Al}_{2} \mathrm{O}_{3}$ is in the range of $2.63-8.15 \times 10^{-4} \mathrm{~mm}^{3} \mathrm{~N}^{-1} \mathrm{~m}^{-1}$, the wear rate against $\mathrm{Si}_{3} \mathrm{~N}_{4}$ is in the range of $2.44-5.83 \times 10^{-4} \mathrm{~mm}^{3} \mathrm{~N}^{-1} \mathrm{~m}^{-1}$, respectively. Generally, the wear rate decreases gradually with the rise of testing temperature. However, for different friction pair material, the variety characteristics of the wear rates are different. For the friction pair of alumina- $\mathrm{Ti}_{2} \mathrm{AlNb}$ tribocouple, it seems higher for $\mathrm{T}>400{ }^{\circ} \mathrm{C}$ compared with $\mathrm{T}<400{ }^{\circ} \mathrm{C}$, meaning that the wear rate decreasing 
tendency is lower for $\mathrm{T}<400{ }^{\circ} \mathrm{C}$. The decreasing tendency of wear rate for alumina- $\mathrm{Ti}_{2} \mathrm{AlNb}$ is higher than that for $\mathrm{Si}_{3} \mathrm{~N}_{4}-\mathrm{Ti}_{2} \mathrm{AlNb}$ system. The $\mathrm{COF}$ behavior was changed near to $500{ }^{\circ} \mathrm{C}$. From Chen et al. [15], it can be found that as temperatures reach $500{ }^{\circ} \mathrm{C}$, the slightly lower COF may be attributed to the lubrication effect of the $\mathrm{TiO}_{2}$ formed in friction surfaces. It is known that $\mathrm{TiO}_{2}$ and $\mathrm{Al}_{2} \mathrm{O}_{3}$ have a contrary effect to the friction coefficient. All the results suggest that the worn surfaces contain much more titanium oxide than aluminium oxide at $500^{\circ} \mathrm{C}$. As a result, the mixed oxides reduce the friction coefficient.

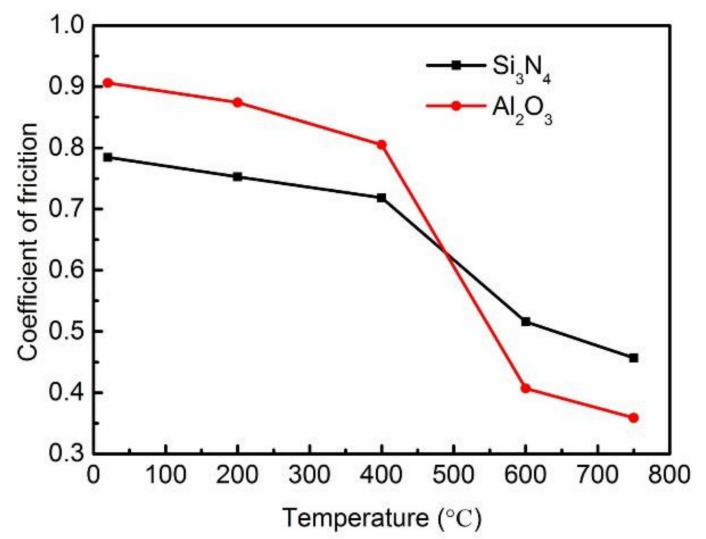

(a)

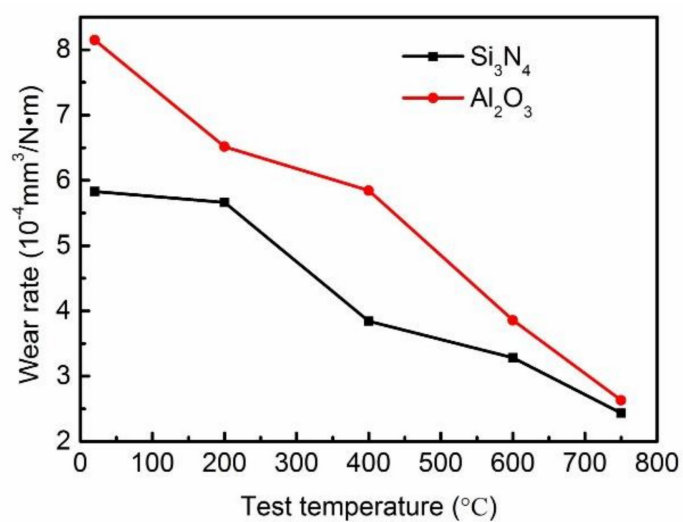

(b)

Figure 3. (a) Coefficient of friction (COF) of the alloy sliding against $\mathrm{Al}_{2} \mathrm{O}_{3}$ and $\mathrm{Si}_{3} \mathrm{~N}_{4}$ at different temperatures, (b) the wear rate of the alloy sliding against $\mathrm{Al}_{2} \mathrm{O}_{3}$ and $\mathrm{Si}_{3} \mathrm{~N}_{4}$ at different temperatures.

\subsection{Wear Surface and Interface Analysis of Ti-22Al-25Nb Alloy}

The friction and wear behavior are related to a material's mechanical properties at different temperatures and wear debris or oxide layer on the worn surfaces generated during sliding. According to Hsu et al.'s viewpoint [16], plastic deformation and its accumulation on the contacting asperities control the wear process when the ambient temperature and sliding speed are not high. As the ambient temperature and/or sliding speed are increased to some extent, the temperature on the contacting asperities starts to control the wear process. Figure 4 is the image of worn surfaces in this alloy against $\mathrm{Al}_{2} \mathrm{O}_{3}$ and $\mathrm{Si}_{3} \mathrm{~N}_{4}$ at various testing temperature. For the counterface materials of $\mathrm{Al}_{2} \mathrm{O}_{3}$ from room temperature to $200^{\circ} \mathrm{C}$ (Figure $4 \mathrm{a}$ ), there is a lot of wear debris on the surface of the Ti-22Al-25Nb alloy and the alloy presented the characteristic of abrasive wear. At $400{ }^{\circ} \mathrm{C}$ (Figure $3 \mathrm{~b}$ ), the wear debris on the surface of the alloy is decreased and the worn surfaces became relatively rougher, with many ripped regions. As the temperature increased to $750{ }^{\circ} \mathrm{C}$, the characteristics of worn surface are different from that of lower temperature. The worn surface was mainly presented adhesive traces (Figure $4 \mathrm{c}$ ). For the counterface materials of $\mathrm{Si}_{3} \mathrm{~N}_{4}$, at the lower temperature $\left(20-400{ }^{\circ} \mathrm{C}\right)$, the tribological characteristics on the surface of the wear tracks are almost similar, showing grooves, wear debris and peeling pits (Figure $4 \mathrm{~d}, \mathrm{e})$. As the temperature increased to higher temperature $\left(400-750{ }^{\circ} \mathrm{C}\right)$, wear characteristics on the surface of the wear tracks are distinctly different (Figure $4 \mathrm{e}, \mathrm{f}$ ). When the temperature increased to $750{ }^{\circ} \mathrm{C}$, the thicker oxide layers were produced on the worn surface. There is very little wear debris on the surface of this alloy, while a large-area tribofilm was found. This means that the wear mechanisms were changed from plastic deformation such as the ploughing and peeling off wear below $400{ }^{\circ} \mathrm{C}$ to adhesive wear above $400{ }^{\circ} \mathrm{C}\left(600\right.$ and $\left.750{ }^{\circ} \mathrm{C}\right)$. Relative to the $\mathrm{Al}_{2} \mathrm{O}_{3}$, the worn surface of Ti-22Al-25Nb alloy against $\mathrm{Si}_{3} \mathrm{~N}_{4}$ exhibits similar variation tendency. Only the wear character is somewhat different at $400{ }^{\circ} \mathrm{C}$. At this temperature, the wear track presents plastic deformation and adhesive wear. Above $400{ }^{\circ} \mathrm{C}$, the wear track is mainly adhesive-wear tribolayers, which may be responsible for the lower wear rate. In order to further analysis wear mechanism, the composition of chemical element on the worn surface is conducted. These results were obtained from EDS which is shown in Table 1. 
In the counter face of the $\mathrm{Al}_{2} \mathrm{O}_{3}$ ball (Figure 5), the wear debris is the oxide of the basis alloy from $200{ }^{\circ} \mathrm{C}$ to $750{ }^{\circ} \mathrm{C}$, the deeper wear track is the Ti-22Al-25Nb alloy. The $\mathrm{Al}_{2} \mathrm{O}_{3}$ wear debris cannot be distinguished in this situation. The element $\mathrm{O}$ was also presented from $200{ }^{\circ} \mathrm{C}$ to $750{ }^{\circ} \mathrm{C}$, which means that the oxidation was happening at these testing temperatures. In the counter face of the $\mathrm{Si}_{3} \mathrm{~N}_{4}$ ball (Figure 5), the wear debris at room temperature mainly contained $\mathrm{Si}_{3} \mathrm{~N}_{4}$ debris and the oxide of the matrix, while the Ti-22Al-25Nb alloy matrix has been oxidized from $200{ }^{\circ} \mathrm{C}$ to $750{ }^{\circ} \mathrm{C}$. The element $\mathrm{Si}$ was mainly presented from $20^{\circ} \mathrm{C}$ to $400{ }^{\circ} \mathrm{C}$. Above $400{ }^{\circ} \mathrm{C}$, the wear trace was composed of the oxide of the basis alloy. It also can be seen that as the test temperature increased, the diameters of the $\mathrm{Al}_{2} \mathrm{O}_{3}$ and $\mathrm{Si}_{3} \mathrm{~N}_{4}$ ball became smaller. The diameter of the $\mathrm{Al}_{2} \mathrm{O}_{3}$ ball is higher than that of the $\mathrm{Si}_{3} \mathrm{~N}_{4}$ ball at same test temperature.

Table 1. Average element composition of the worn areas of the Ti-22Al-25Nb alloy (at. \%) at different counterface materials and temperatures obtained by energy dispersive spectroscopy (EDS).

\begin{tabular}{ccc}
\hline Position & Testing Temperature $\left({ }^{\circ} \mathrm{C}\right)$ & Average Composition (at.\%) \\
\hline 1 & $200{ }^{\circ} \mathrm{C}$ & $\mathrm{O}_{61.1} \mathrm{Al}_{23.5} \mathrm{Ti}_{9.9} \mathrm{Nb}_{5.5}$ \\
2 & $200^{\circ} \mathrm{C}$ & $\mathrm{O}_{47.8} \mathrm{Al}_{28.9} \mathrm{Ti}_{16.3} \mathrm{Nb}_{7.0}$ \\
3 & $200^{\circ} \mathrm{C}$ & $\mathrm{O}_{47.1} \mathrm{Al}_{31.4} \mathrm{Ti}_{14.0} \mathrm{Nb}_{7.5}$ \\
4 & $400^{\circ} \mathrm{C}$ & $\mathrm{O}_{56.0} \mathrm{Al}_{16.8} \mathrm{Ti}_{18.4} \mathrm{Nb}_{8.8}$ \\
5 & $400^{\circ} \mathrm{C}$ & $\mathrm{O}_{59.5} \mathrm{Al}_{17.1} \mathrm{Ti}_{15.3} \mathrm{Nb}_{8.1}$ \\
6 & $400^{\circ} \mathrm{C}$ & $\mathrm{O}_{24.8} \mathrm{Al}_{13.7} \mathrm{Ti}_{40.8} \mathrm{Nb}_{20.7}$ \\
7 & $750{ }^{\circ} \mathrm{C}$ & $\mathrm{O}_{44.1} \mathrm{Al}_{9.9} \mathrm{Ti}_{31.3} \mathrm{Nb}_{14.7}$ \\
8 & $750^{\circ} \mathrm{C}$ & $\mathrm{O}_{58.2} \mathrm{Al}_{7.6} \mathrm{Ti}_{22.9} \mathrm{Nb}_{11.3}$ \\
9 & $750^{\circ} \mathrm{C}$ & $\mathrm{O}_{57.6} \mathrm{Al}_{8.4} \mathrm{Ti}_{22.4} \mathrm{Nb}_{11.6}$ \\
10 & $200^{\circ} \mathrm{C}$ & $\mathrm{O}_{41.9} \mathrm{Al}_{11.3} \mathrm{Si}_{6.2} \mathrm{Ti}_{26.7} \mathrm{Nb}_{13.9}$ \\
11 & $200^{\circ} \mathrm{C}$ & $\mathrm{O}_{12.0} \mathrm{Al}_{16.1} \mathrm{Si}_{3.9} \mathrm{Ti}_{45.5} \mathrm{Nb}_{22.5}$ \\
12 & $200^{\circ} \mathrm{C}$ & $\mathrm{O}_{38.2} \mathrm{Al}_{11.4} \mathrm{Si}_{6.4} \mathrm{Ti}_{28.7} \mathrm{Nb}_{15.3}$ \\
13 & $400^{\circ} \mathrm{C}$ & $\mathrm{O}_{57.1} \mathrm{Al}_{8.6} \mathrm{Si}_{1.1} \mathrm{Ti}_{22.1} \mathrm{Nb}_{11.1}$ \\
14 & $400^{\circ} \mathrm{C}$ & $\mathrm{O}_{24.3} \mathrm{Al}_{13.3} \mathrm{Si}_{1.7} \mathrm{Ti}_{41.0} \mathrm{Nb}_{19.7}$ \\
15 & $750{ }^{\circ} \mathrm{C}$ & $\mathrm{O}_{50.2} \mathrm{Al}_{7.7} \mathrm{Ti}_{28.6} \mathrm{Nb}_{13.5}$ \\
16 & $750^{\circ} \mathrm{C}$ & $\mathrm{O}_{45.4} \mathrm{Al}_{9.6} \mathrm{Ti}_{28.8} \mathrm{Nb}_{16.2}$ \\
\hline
\end{tabular}

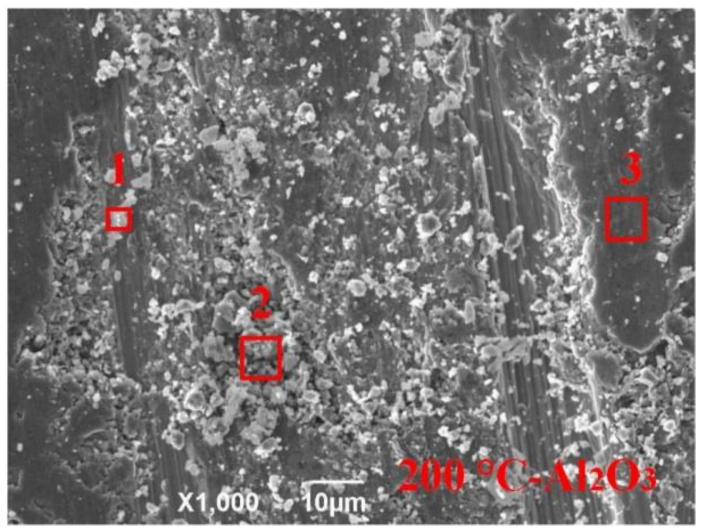

(a)

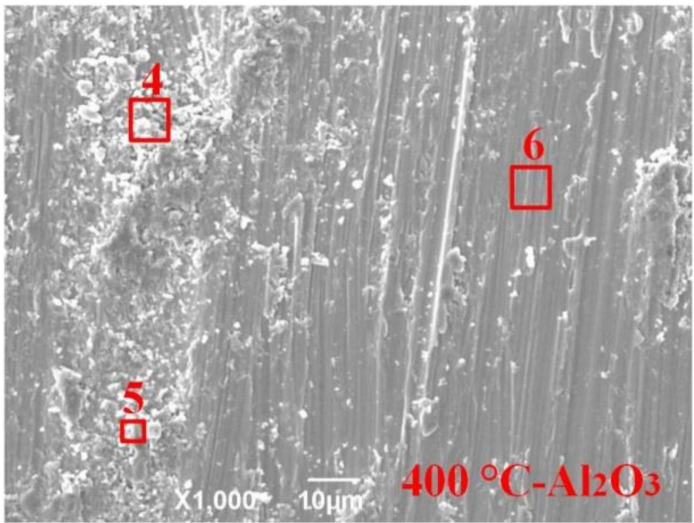

(b)

Figure 4. Cont. 


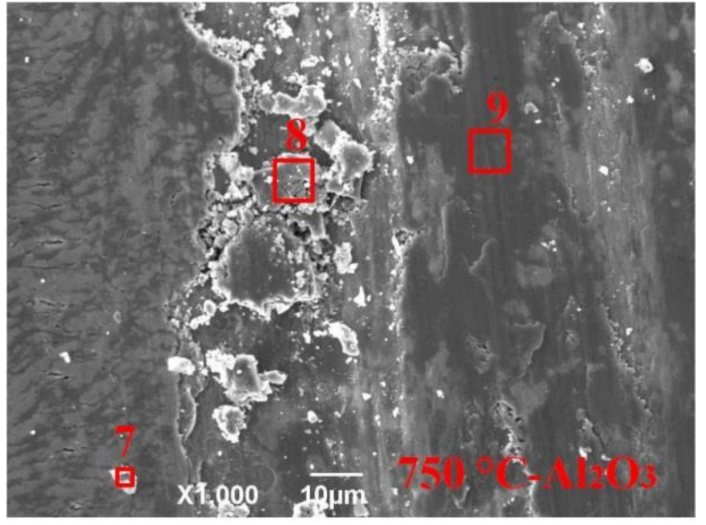

(c)

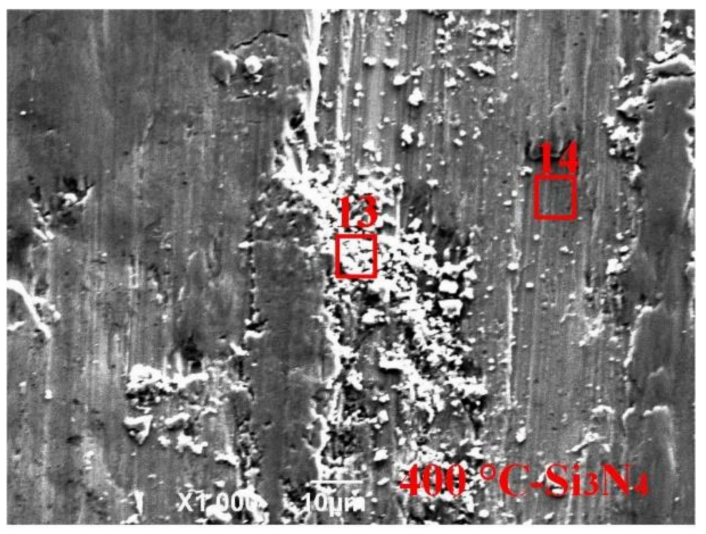

(e)

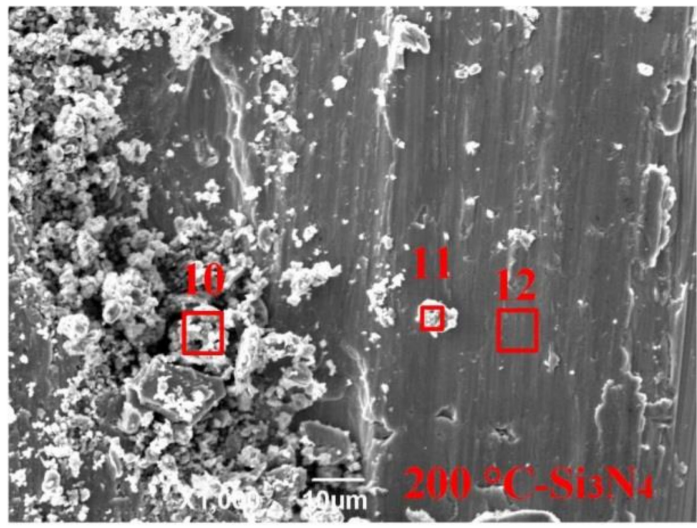

(d)

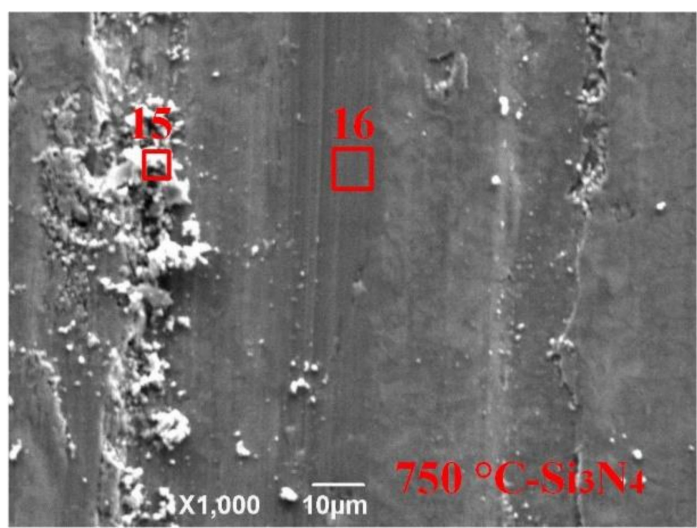

(f)

Figure 4. The worn surfaces of the alloy against $\mathrm{Al}_{2} \mathrm{O}_{3}$ and $\mathrm{Si}_{3} \mathrm{~N}_{4}$ at different testing temperatures $(\mathbf{a}) \mathrm{Al}_{2} \mathrm{O}_{3}$ $200{ }^{\circ} \mathrm{C}$, (b) $\mathrm{Al}_{2} \mathrm{O}_{3}-400{ }^{\circ} \mathrm{C}$, (c) $\mathrm{Al}_{2} \mathrm{O}_{3}-750{ }^{\circ} \mathrm{C}$, (d) $\mathrm{Si}_{3} \mathrm{~N}_{4}-200{ }^{\circ} \mathrm{C}$, (e) $\mathrm{Si}_{3} \mathrm{~N}_{4}-400{ }^{\circ} \mathrm{C}$, (f) $\mathrm{Si}_{3} \mathrm{~N}_{4}-750{ }^{\circ} \mathrm{C}$.

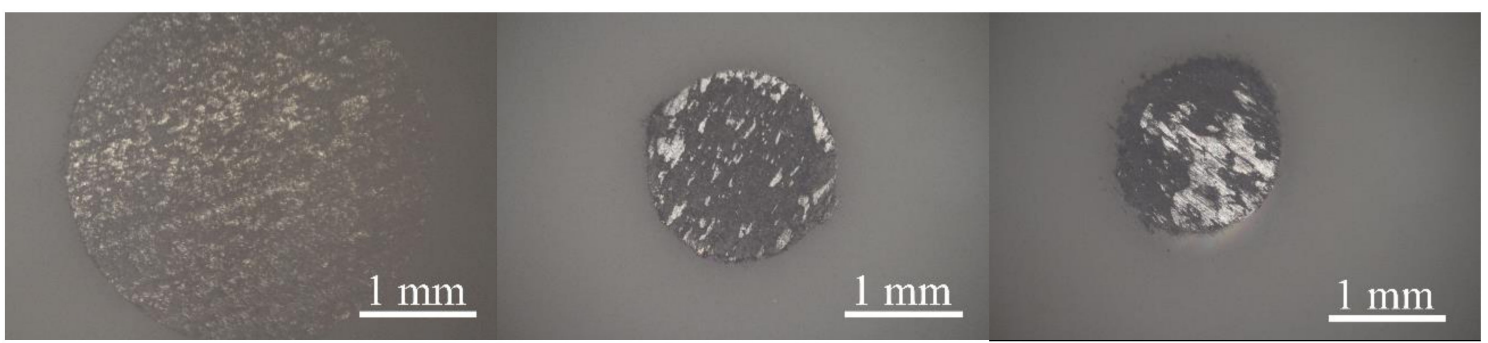

(a)

(b)

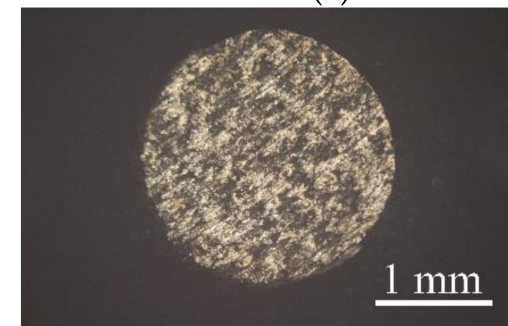

(d) (c)

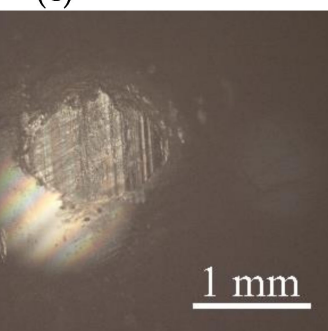

(f)

Figure 5. The worn surfaces of the alloy against $\mathrm{Al}_{2} \mathrm{O}_{3}$ and $\mathrm{Si}_{3} \mathrm{~N}_{4}$ at different testing temperatures. (a) $\mathrm{Al}_{2} \mathrm{O}_{3}-200{ }^{\circ} \mathrm{C}$; (b) $\mathrm{Al}_{2} \mathrm{O}_{3}-400{ }^{\circ} \mathrm{C}$; (c) $\mathrm{Al}_{2} \mathrm{O}_{3}-750{ }^{\circ} \mathrm{C}$; (d) $\mathrm{Si}_{3} \mathrm{~N}_{4}-200{ }^{\circ} \mathrm{C}$; (e) $\mathrm{Si}_{3} \mathrm{~N}_{4}-400{ }^{\circ} \mathrm{C}$; (e) $\mathrm{Si}_{3} \mathrm{~N}_{4}-750{ }^{\circ} \mathrm{C}$. 
Figures 6 and 7 show the images of the worn surfaces of this alloy vs. $\mathrm{Al}_{2} \mathrm{O}_{3}$ and $\mathrm{Si}_{3} \mathrm{~N}_{4}$ at different testing temperatures, respectively. It can be seen that the width of the lower specimens from the $\mathrm{Al}_{2} \mathrm{O}_{3}$ ball is much wider than that from the $\mathrm{Si}_{3} \mathrm{~N}_{4}$ ball. The main reason is that the $\mathrm{Al}_{2} \mathrm{O}_{3}$ ball has lower fracture toughness [15]. So, during friction processing, the wear trace of $\mathrm{Al}_{2} \mathrm{O}_{3}$ ball is bigger [15]. It also was found that sharper, deeper abrasive grooves and more abundant, fine oxide particles are formed below $200{ }^{\circ} \mathrm{C}$. As the temperature increased, the fine oxide particles are decreased, the width of the wear track is decreased, and the depth of the wear crack are increased. From the analyses of the profiles of the worn surfaces, it is concluded that the highest test temperature $\left(750{ }^{\circ} \mathrm{C}\right)$ has the best wear resistance. The oxide layer of the worn surface may have an important role.
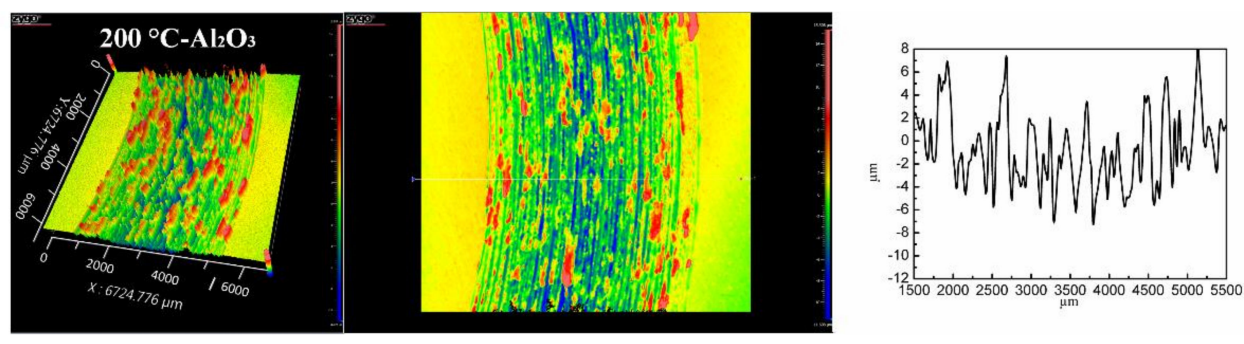

(a)
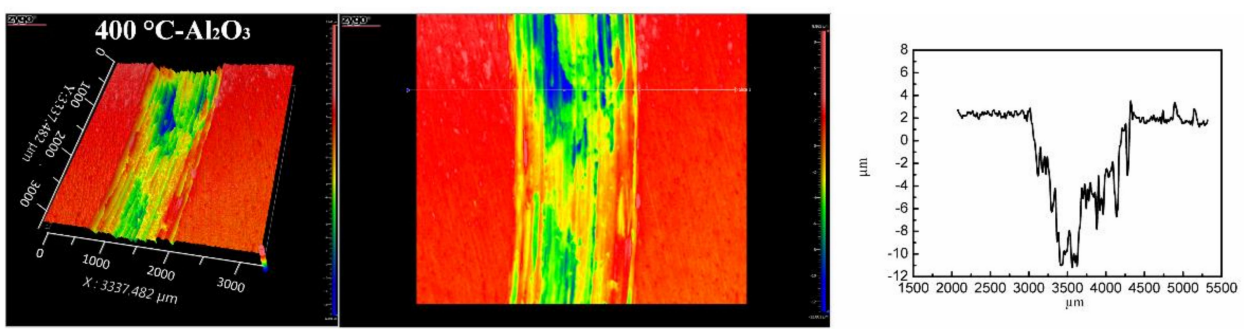

(b)
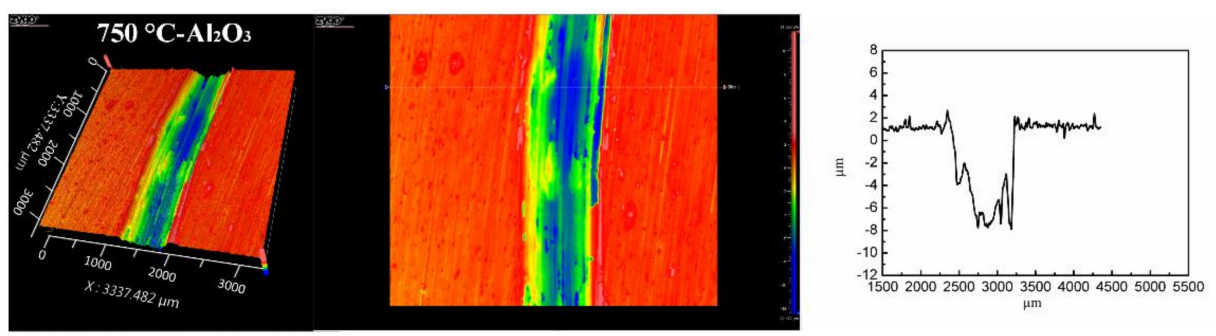

(c)

Figure 6. 3D images and profiles of the worn surfaces of the Ti-22Al-25Nb alloy vs. $\mathrm{Al}_{2} \mathrm{O}_{3}$ at different testing temperatures, (a) $\mathrm{Al}_{2} \mathrm{O}_{3}-200{ }^{\circ} \mathrm{C}$, (b) $\mathrm{Al}_{2} \mathrm{O}_{3}-400{ }^{\circ} \mathrm{C}$, (c) $\mathrm{Al}_{2} \mathrm{O}_{3}-750{ }^{\circ} \mathrm{C}$
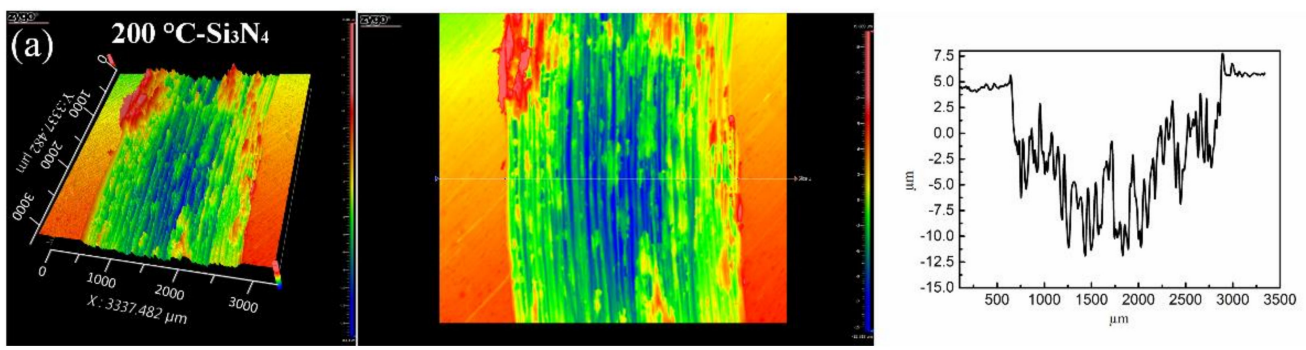

Figure 7. Cont. 
(a)
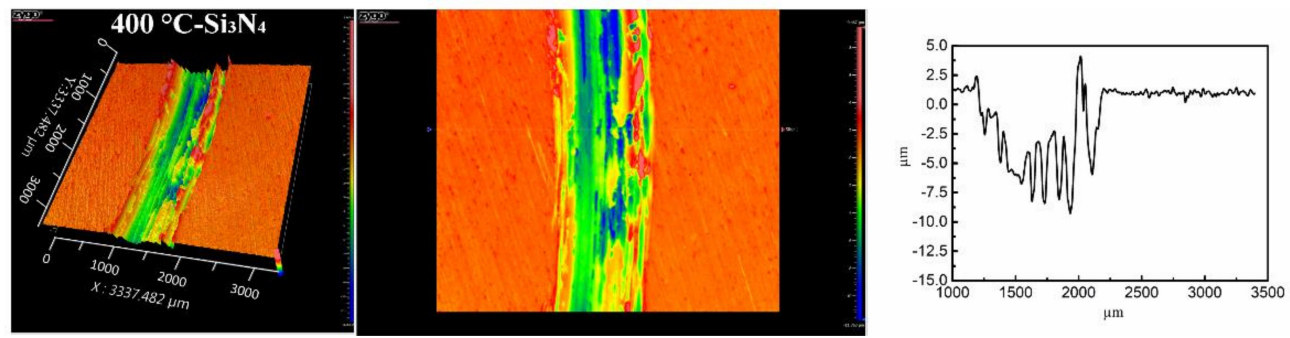

(b)
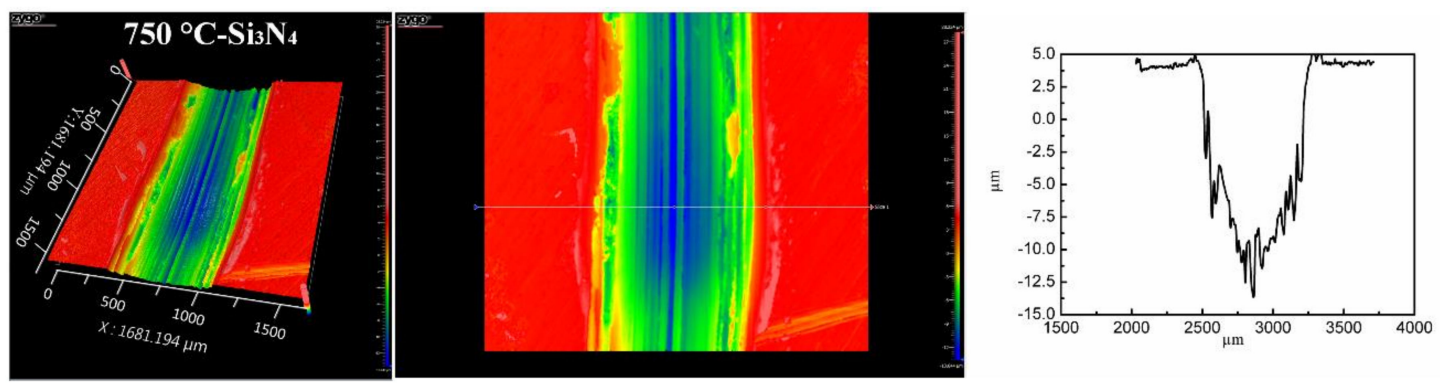

(c)

Figure 7. 3D images and profiles of the worn surfaces of the Ti-22Al-25Nb alloy vs. $\mathrm{Si}_{3} \mathrm{~N}_{4}$ at different testing temperatures. (a) $\mathrm{Si}_{3} \mathrm{~N}_{4}-200{ }^{\circ} \mathrm{C}$, (b) $\mathrm{Si}_{3} \mathrm{~N}_{4}-400{ }^{\circ} \mathrm{C}$, (c) $\mathrm{Si}_{3} \mathrm{~N}_{4}-750{ }^{\circ} \mathrm{C}$

In order to further explain the role of the oxide layer, especially the products on the higher temperature, XRD and XPS analysis were conducted on Figures 8 and 9, respectively. XRD results for the worn surfaces of Ti-22Al-25Nb alloy under various temperatures are shown in Figure 8. At room temperature, $\mathrm{B} 2+\mathrm{O}$ phases were the predominant phase, and hardly any tribo-oxide was identified. At lower temperature $\left(<400{ }^{\circ} \mathrm{C}\right), \mathrm{TiO}_{2}$ and $\mathrm{Al}_{2} \mathrm{O}_{3}$ are the main oxides, while at higher temperature $\left(>400{ }^{\circ} \mathrm{C}\right.$ ), the new oxides such as $\mathrm{AlNbO}_{4}$ and $\mathrm{Ti}_{3} \mathrm{Al}_{2} \mathrm{~N}_{2}$ were found on the worn surface, while the $\mathrm{TiO}_{2}$ and $\mathrm{Al}_{2} \mathrm{O}_{3}$ are also the dominant oxide phase. The formation of nitrous oxide was due to the diffusion of the nitrogen in the atmosphere. It seemed that the formation of the mixed oxides has an important role in the friction process. Form previous results, it has been found that the oxides of the worn surface are beneficial for improving the lubricating properties. In order to further identify the chemical state of the surface element such as element $\mathrm{Al}, \mathrm{O}$ and Ti, XPS analysis of the worn surfaces at different temperatures was conducted on Figure 9. At lower temperature $\left(20-200{ }^{\circ} \mathrm{C}\right)$, based on the EDS and XPS results, it can be found that the oxides on the worn surface are much less, thus in this temperature range Ti-22Al-25Nb alloy has higher COF. When the temperature increased to 400 and $600{ }^{\circ} \mathrm{C}$, the oxides on the worn surface were also increased, so the COF was decreased. This phenomenon is similar to that in reference [9], the $\mathrm{TiO}_{2}$ which was formed on the surface has an important role for decreasing friction and wear. From the above analysis, the $\mathrm{TiO}_{2}$ and $\mathrm{Al}_{2} \mathrm{O}_{3}$ are the main oxides of the worn surface. From reference [17], two oxides have different role for reducing friction and wear. At higher temperature $\left(400\right.$ and $\left.600{ }^{\circ} \mathrm{C}\right)$, the quantity of $\mathrm{TiO}_{2}$ is more than that of $\mathrm{Al}_{2} \mathrm{O}_{3}$. The $\mathrm{TiO}_{2}$ layer has positive effects for decreasing friction and wear of this alloy, while $\mathrm{Al}_{2} \mathrm{O}_{3}$ is beneficial for improving friction and wear [13-17]. The quantity of $\mathrm{TiO}_{2}$ is more in the mixed oxides, so the total roles of these mixed oxides are beneficial for reducing COF. From above results, it can be seen that as the test temperature increased to a higher temperature $\left(750{ }^{\circ} \mathrm{C}\right)$, the quantity of $\mathrm{Al}_{2} \mathrm{O}_{3}$ increases a little. So the reduced velocity of COF became slower. 


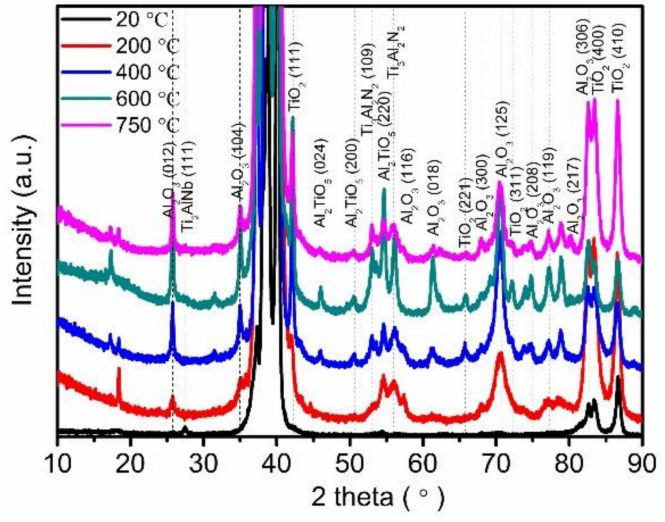

(a)

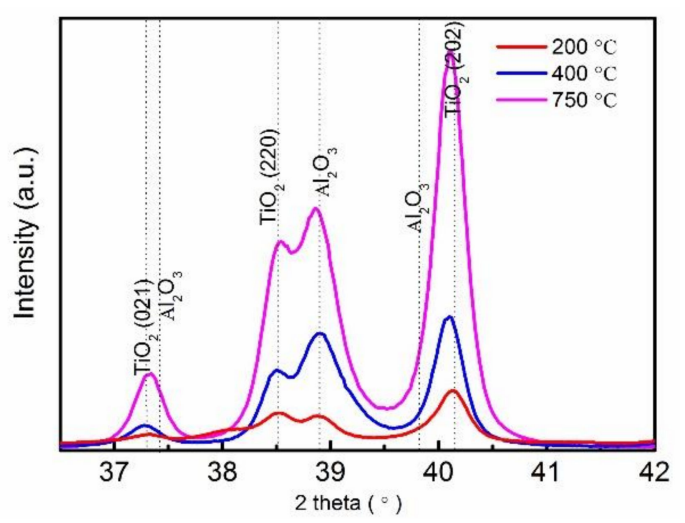

(b)

Figure 8. $\mathrm{XRD}$ patterns of the alloy vs. $\mathrm{Al}_{2} \mathrm{O}_{3}$ at different temperature (a) the overall picture (b) the local picture.

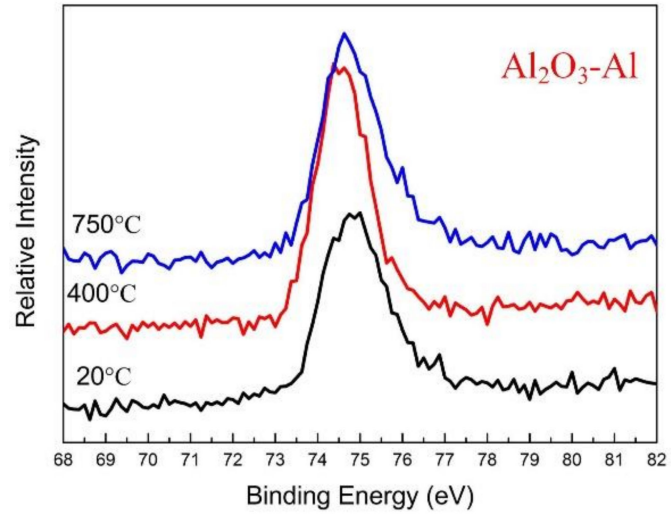

(a)

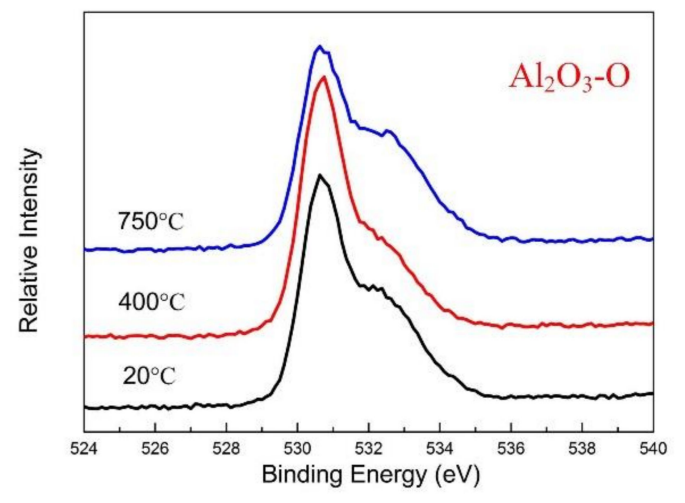

(c)

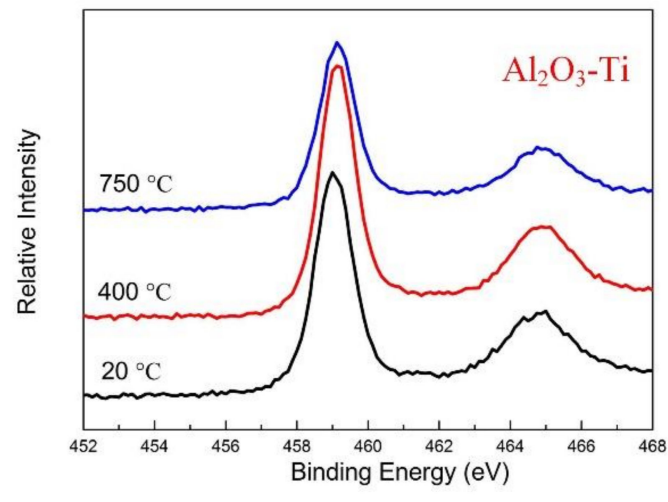

(b)

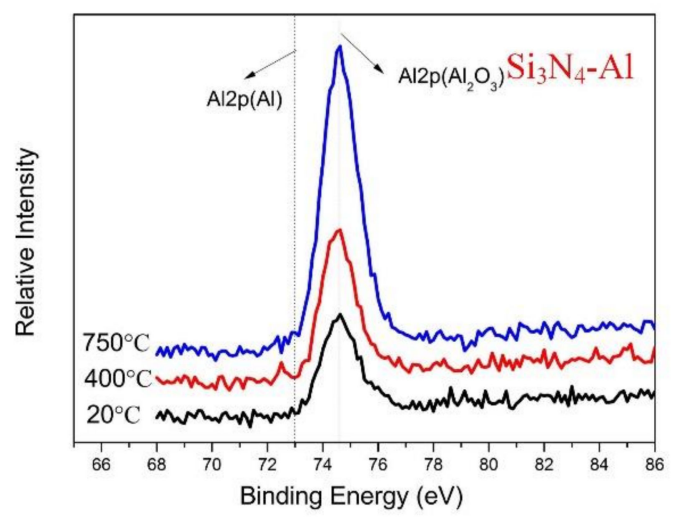

(d)

Figure 9. Cont. 


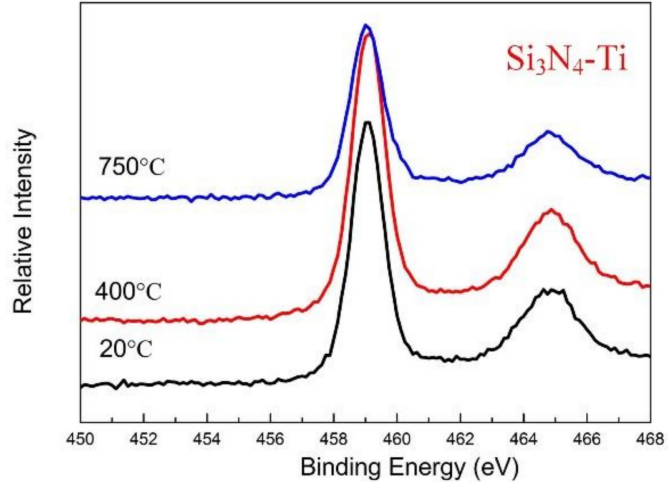

(e)

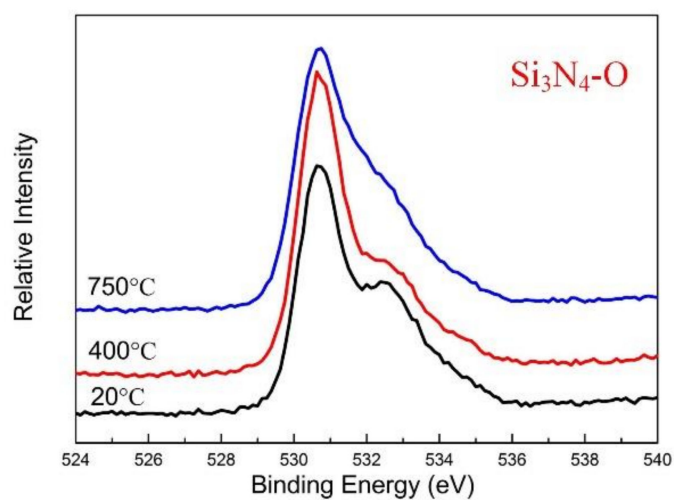

(f)

Figure 9. X-ray photoelectron spectroscopy (XPS) spectra of $\mathrm{Al}, \mathrm{Ti}$, and $\mathrm{O}$ on the worn surfaces of the Ti-22Al-25Nb alloy at different temperatures with the friction pair of $\mathrm{Al}_{2} \mathrm{O}_{3}$ and $\mathrm{Si}_{3} \mathrm{~N}_{4}$. (a) XPS of $\mathrm{Al}$ with the friction pair of $\mathrm{Al}_{2} \mathrm{O}_{3}$ at different temperature, (b) XPS of Ti with the friction pair of $\mathrm{Al}_{2} \mathrm{O}_{3}$ at different temperature, (c) XPS of $\mathrm{O}$ with the friction pair of $\mathrm{Al}_{2} \mathrm{O}_{3}$ at different temperature, (d) XPS of Al with the friction pair of $\mathrm{Si}_{3} \mathrm{~N}_{4}$ at different temperature, (e) XPS of Ti with the friction pair of $\mathrm{Si}_{3} \mathrm{~N}_{4}$ at different temperature, (f) XPS of $\mathrm{O}$ with the friction pair of $\mathrm{Si}_{3} \mathrm{~N}_{4}$ at different temperature.

Except for the worn surface, the tribo-layer is a very important factor for evaluating the tribological performance of alloys. Thus, the research about the tribo-layer of this alloy is essential. Figure 10 shows the friction layer at the different counterface materials from 200 to $750{ }^{\circ} \mathrm{C}$. It can be seen that the friction layer is different from the matrix. It contained the worn surface, mechanical mixing layer and matrix. The tribo-films are changed as the temperature increased, especially the thickness of the tribo-layer. In current research, for two different counterface materials, the tribo-layer is very similar. At a lower temperature (Figure 10a,c), the tribo-layer is not obvious, while as the temperature increased to $750{ }^{\circ} \mathrm{C}$ (Figure $10 \mathrm{~b}, \mathrm{~d}$ ), there existed a $10 \mu \mathrm{m}$-thickness plastically deformed layer. It can be speculated that most loose tribolayers might flake off under the action of frictional and normal force [18]. At lower temperature, the tribo-layer is not compact. However, at higher temperature, the tribo-layers became not only continuous but also compact. The thickness of the tribo-layers is increased. The formation of the tribo-layers is related to the higher strength and better thermal stability of Ti-22Al-25Nb.

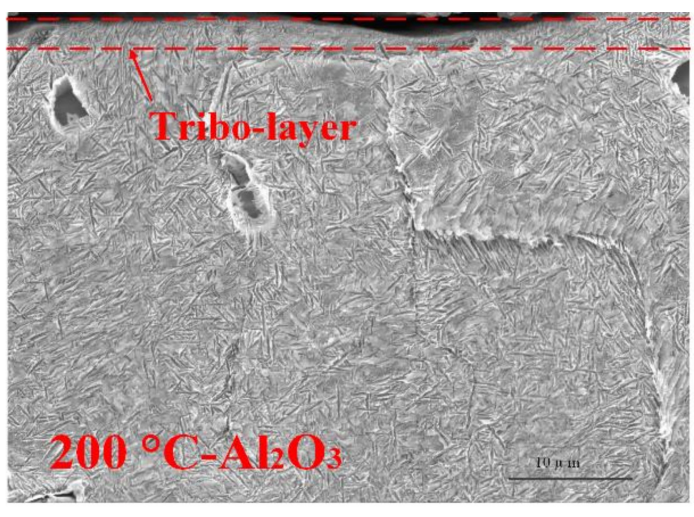

(a)

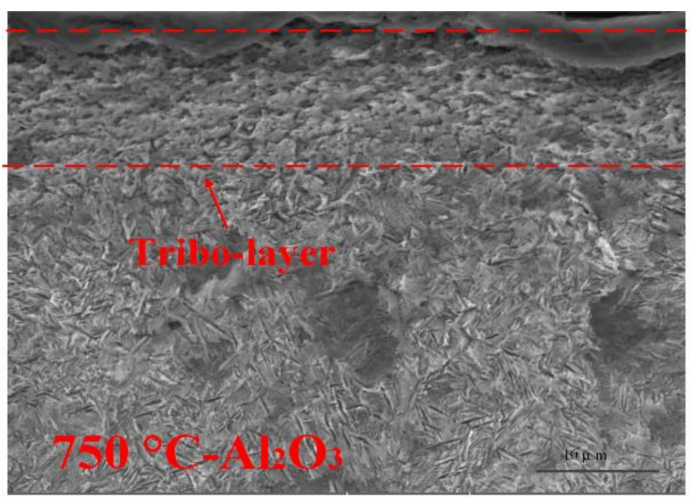

(b)

Figure 10. Cont. 


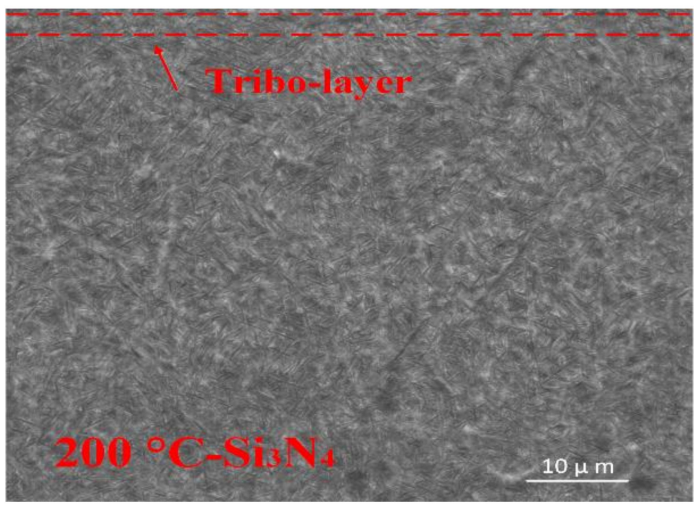

(c)

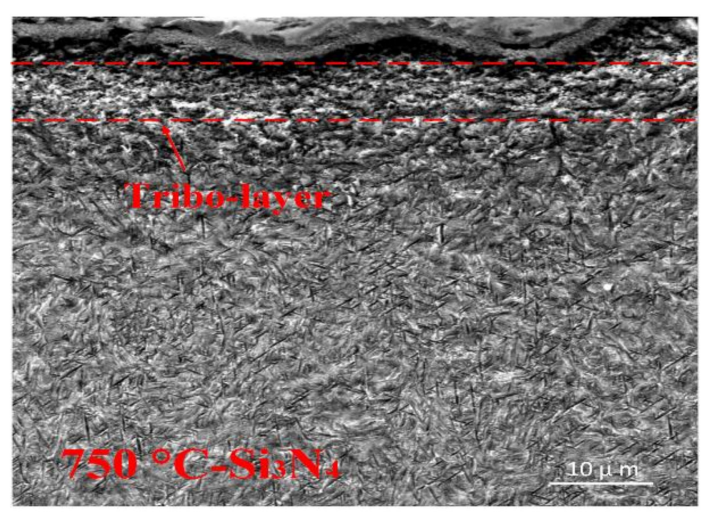

(d)

Figure 10. SEM micrographs of cross sections showing friction layer of the alloy vs. $\mathrm{Al}_{2} \mathrm{O}_{3}$ at $200{ }^{\circ} \mathrm{C}$ (a) and $750{ }^{\circ} \mathrm{C}(\mathbf{b})$, friction layer of the alloy vs. $\mathrm{Si}_{3} \mathrm{~N}_{4}$ at $200{ }^{\circ} \mathrm{C}$ (c) and $750{ }^{\circ} \mathrm{C}$ (d).

\subsection{High-Temperature Friction Mechanism of Ti-22Al-25Nb Alloy}

From the above analysis, it can be seen that tribological properties of Ti-22Al-25Nb alloy at different experimental temperature ranges present the various COFs and wear characteristics. The tribological properties of this alloy at different temperature range are various. COF and wear of this alloy are related to the test temperature. The friction oxides formed on the worn surface have a significant effect on wear behavior and wear mechanism. In the region with the oxide layer, the frictional oxide layer has the function of covering and protecting the surface of the metal. The wear mechanism is the spalling of oxide layer; in the area without the frictional oxide layer, the surface of titanium alloy presented the plastic deformation. From the experimental results, at lower temperature (room temperature to $400{ }^{\circ} \mathrm{C}$ ), $\mathrm{COFs}$ of this alloy are very high and not stable. There are two reasons to explain this phenomenon. First, the fragmented particles were produced in the friction process. This is the reason for increasing COF. Second, the oxidation on the surface of titanium alloy has positive effects for reducing $\mathrm{COF}$ and wear [15]. However, when the temperature was increased to $750{ }^{\circ} \mathrm{C}$, $\mathrm{Al}_{2} \mathrm{O}_{3}$ is the main content in the oxidation of the surface. It is not beneficial to reduce the COF. These results can be found from the XPS analysis. From room temperature to $400{ }^{\circ} \mathrm{C}$, surface oxidation is relatively low and the alloy does not experience brittle-to-ductile transition. In this temperature range, smaller and loose particles were produced by friction processing from the brittle and hard oxide. The schematic diagram of high-temperature tribological behavior of Ti-22Al-25Nb alloy is shown in Figure 11 . However, when the temperature was increased, especially $600-750{ }^{\circ} \mathrm{C}$, the oxidation rate was increased and the wear particles were decreased. The wear mechanism was controlled by ductile qualities [16-19].

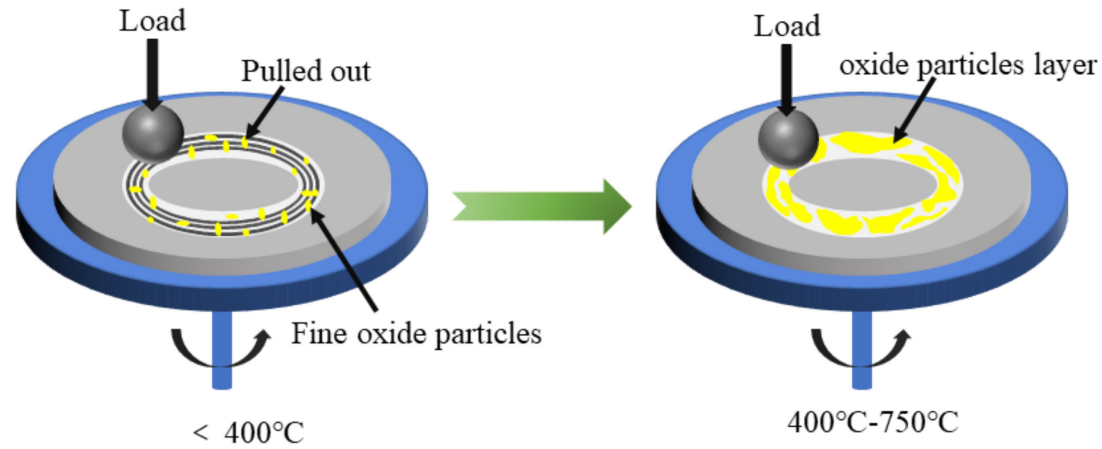

Figure 11. The schematic diagram of high temperature tribological behavior of Ti-22Al-25Nb alloy. 


\section{Conclusions}

In this paper, the high-temperature tribological properties of the Ti-22Al-25Nb alloy with lamellar $\mathrm{O}$ microstructures were studied. The $\mathrm{COF}$ and wear rate are strongly dependent on the experimental temperatures. The COFs of two counterface materials were different; the COF of $\mathrm{Al}_{2} \mathrm{O}_{3}$ is higher than that of $\mathrm{Si}_{3} \mathrm{~N}_{4}$ below $400{ }^{\circ} \mathrm{C}$, while the trends go in the other direction at $400-750{ }^{\circ} \mathrm{C}$. At higher temperatures, this alloy has higher wear resistance due to the oxides on the worn surface. At lower temperature $\left(20-400^{\circ} \mathrm{C}\right)$, the ploughing and peeling off wear were the main factors, while at the higher temperature $\left(400-750^{\circ} \mathrm{C}\right)$, the wear mechanism was changed into oxidative and adhesive wear.

Author Contributions: W.W., Q.W., J.J. and K.W. conceived and designed the experiments; W.W., Y.S. and H.Z. performed the experiments and analyzed the data; W.W. wrote the paper.

Funding: This work was supported by the fund of the State Key Laboratory of Solidification Processing in NWPU (No. SKLSP201828), the National Natural Science Foundation of China (No. 51605249) and the China Postdoctoral Science Foundation (No. 2016M601010, 2017T10086).

Acknowledgments: The authors thank the National Key Laboratory of Tribology (SKLT) from Tsinghua University for performing various tribological experiments.

Conflicts of Interest: The authors declare no conflict of interest.

\section{References}

1. Banerjee, D.; Gogia, A.K.; Nandy, T.K.; Joshi, V.A. A New Ordered Orthorhombic Phase in a Ti3Al-Nb Alloy. Acta Metall. 1988, 36, 871-882. [CrossRef]

2. Wang, W.; Zeng, W.; Sun, Y.; Zhou, H.; Liang, X. Microstructure, Tensile, and Creep Behaviors of Ti-22Al-25Nb (at.\%) Orthorhombic Alloy with Equiaxed Microstructure. Materials 2018, 11, 1244. [CrossRef] [PubMed]

3. Zheng, Y.; Zeng, W.; Li, D.; Zhao, Q.; Liang, X.; Zhang, J.; Ma, X. Fracture toughness of the bimodal size lamellar O phase microstructures in Ti-22Al-25Nb (at.\%) orthorhombic alloy. J. Alloys Compd. 2017, 709, 511-518. [CrossRef]

4. Wang, Y.; Cai, X.Q.; Yang, Z.W.; Wang, D.P.; Liu, X.G.; Liu, Y.C. Effects of Nb content in Ti-Ni-Nb brazing alloys on the microstructure and mechanical properties of Ti-22Al-25Nb alloy brazed joints. J. Mater. Sci. Technol. 2017, 33, 682-689. [CrossRef]

5. Zheng, Y.; Zeng, W.; Zhao, Q.; Li, D.; Ma, X.; Liang, X.; Zhang, J. Deformation and microstructure evolution above the B2 transus of Ti-22Al-25Nb (at\%) orthorhombic alloy. Mater. Sci. Eng. A 2018, 710, 164-171. [CrossRef]

6. Lin, P.; Hao, Y.; Zhang, B.; Zhang, S.; Shen, J. Strain rate sensitivity of Ti-22Al-25Nb (at\%) alloy during high temperature deformation. Mater. Sci. Eng. A 2018, 710, 336-342. [CrossRef]

7. Wang, W.; Zeng, W.; Li, D.; Zhu, B.; Zheng, Y.; Liang, X. Microstructural evolution and tensile behavior of Ti2AlNb alloys based $\alpha 2$-phase decomposition. Mater. Sci. Eng. A 2016, 662, 120-128. [CrossRef]

8. Zhang, J.W.; Li, S.Q.; Liang, X.B.; Cheng, Y.J. Research and application of Ti3Al and Ti2AlNb based alloys. Chin. J. Nonferrous Met. 2010, 20, 336-341.

9. Wu, H.Y.; Zhang, P.Z.; Xu, Z. Study on nanomechanical and high temperature tribological behaviour of Ti2AlNb based alloys by plasma surface alloying. Surf. Eng. 2013, 24, 464-469. [CrossRef]

10. Mi, G.; Yao, K.; Bai, P.; Cheng, C.; Min, X. High Temperature Oxidation and Wear Behaviors of Ti-V-Cr Fireproof Titanium Alloy. Metals 2017, 7, 226. [CrossRef]

11. Li, C.X.; Xia, J.; Dong, H. Sliding wear of TiAl intermetallics against steel and ceramics of Al2O3, Si3N4 and WC/Co. Wear 2006, 261, 693-701. [CrossRef]

12. Alam, M.O.; Haseeb, A.S.M.A. Response of Ti-6Al-4V and Ti-24Al-11Nb alloys to dry sliding wear against hardened steel. Tribol. Int. 2002, 35, 357-362. [CrossRef]

13. Rastkar, A.R.; Bloyce, A.; Bell, T. Sliding wear behaviour of two gamma-based titanium aluminides. Wear 2000, 240, 19-26. [CrossRef]

14. Miyoshi, K.; Lerch, B.A.; Draper, S.L.; Raj, S.V. Evaluation of Ti-48A1-2Cr-2Nb under Fretting Condition. NASA/TM-2001-211205; NASA Glenn Research Center: Cleveland, OH, USA, 2001.

15. Cheng, J.; Li, F.; Qiao, Z.H.; Zhu, S.Y.; Yang, J.; Liu, W.M. The role of oxidation and counterface in the high temperature tribological properties of TiAl intermetallics. Mater. Des. 2015, 84, 245-253. [CrossRef] 
16. Hsu, S.M.; Shen, M.C.; Ruff, A.W. Wear prediction for metals. Tribol. Int. 1997, 30, 377-383. [CrossRef]

17. XU, Z.S.; Zhang, Q.X.; Jing, P.X.; Zhai, W.Z. High-Temperature Tribological Performance of TiAl Matrix Composites Reinforced by Multilayer Graphene. Tribol. Lett. 2015, 58, 1-9. [CrossRef]

18. Wang, L.; Zhang, Q.Y.; Li, X.X.; Cui, X.H.; Wang, S.Q. Severe-to-Mild Wear Transition of Titanium Alloys as a Function of Temperature. Tribol. Lett. 2014, 53, 511-520. [CrossRef]

19. Rigney, D.A. Some thoughts on sliding wear. Wear 1992, 152, 187-192. [CrossRef]

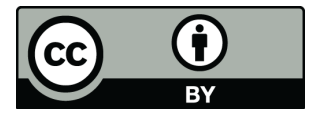

(C) 2018 by the authors. Licensee MDPI, Basel, Switzerland. This article is an open access article distributed under the terms and conditions of the Creative Commons Attribution (CC BY) license (http:/ / creativecommons.org/licenses/by/4.0/). 